\title{
Changes in the photosynthetic apparatus of plants on chosen roads in Białystok
}

\author{
Grażyna Laska \\ Department of Environmental Protection and Management, Białystok Technical University, \\ Wiejska 45a, 15-351 Białystok, Poland; e-mail: g.laska@pb.edu.pl
}

\begin{abstract}
Variation in the photosynthetic apparatus of plants, in relation to the species composition and structure of plant communities, has been studied in transects along selected roads in Białystok, characterised with various intensity of traffic. Concentrations of total chlorophyll, chlorophyll a and b and carotenoids were measured in green biomass from 3 non-forest transects and 1 forest transect localised along the main roads. The concentrations of chlorophyll in green biomass from the city transects were compared with those from two reference transects in the centre of Knyszyńska Forest, beyond direct impact of road traffic. The effect of the distance of transects from the roads (4-5 m, 14-15 m and 24-25 m) and the main groups of species making plant communities (in green biomass of trees, bushes, herbal plants and moss) was also analysed.

The concentration of total chlorophyll in green biomass from non-forest transects varies from $29.8 \mathrm{mg} / \mathrm{g}$ fresh mass to $66.1 \mathrm{mg} / \mathrm{g}$ fresh mass, while it is $38.3 \mathrm{mg} / \mathrm{g}$ fresh mass from the reference transect, outside the city and beyond direct influence of road traffic. The analogous values of total chlorophyll concentration in green biomass from the forest transects are higher than in the green biomass from non-forest transects, both in the city (70.9 mg/g fresh mass) and from the reference transect (90.4 mg/g fresh mass). According to the results, the content of total chlorophyll in plants is correlated with the intensity of traffic and the distance from the road. Changes in the photosynthetic apparatus depend also on the vertical structure and species composition of the vegetation patches studied. Higher concentrations of chlorophyll in the plants growing in the forest transect than in those in non-forest ones in the city points to the greater role of forested areas as a biological barrier. Their biological effectiveness considerably depends on the floristic composition, so the selection of species in designing of green areas should be made taking into account the effect of seasonal changes and density of individuals per a unit area.
\end{abstract}

Key words: roads, traffic, forest and non forest transect, total chlorophyll, chlorophyll a, chlorophyll b, carotenoids.

\section{Introduction}

Chlorophylls a and b are the most important leaf pigments and the absorption of solar radiation by chlorophyll is the first stage of the photosynthetic pathway (Porra 2002; Silla et al. 2010; Lamb et al. 2012). The leaf chlorophyll content is a crucial parameter for many biological studies related to the physiological status of plants (Hörtensteiner \& Kräutler 2000; Radyuk \& Homan 2002; Sanmartin et al. 2011). The amount and type of chlorophyll present within a photosynthetic organism was found to vary with the availability of nutrients (Timperio et al. 2007), disease (Scarpari et al. 2005) and heat stress (Camejo et al. 2005). The amount of chlorophyll in photosynthetic organisms is an important parameter, particularly that of chlorophyll a, which is the primary photosynthetic pigment in nearly all known oxygenic photosynthetic organisms. The photosynthetic activity is related to the content of this photosynthetic pigment, chlorophyll a (MacIntyre et al. 2002; Rüdiger 2002). The content of chlorophyll a or total chlorophyll (chlorophyll $\mathrm{a}+\mathrm{b}$ ) is used as the standard basis on which to calculate photosynthetic and respiratory rates or the metabolically active biomass and the productivity of terrestrial and aquatic ecosystems (Ritchie 2006). The presence or absence of other chlorophylls (b, c1, c2, c3 and d) is of taxonomic importance. The relative amounts of chlorophyll $b$ in vas- 
cular plants compared to chlorophyll a varies with both light intensity and the spectral quality of light (Porra 2002).

Total chlorophyll contents and related chlorophyll parameters can be used as the indices informing about the nutrient status (Moran et al. 2000; Chang \& Robinson 2003; Berg \& Perkins 2004), physiological stress (Neufeld et al. 2006; Peguero-Pina et al. 2008; Daas et al. 2008) and changes in abiotic factors (Gratani et al. 2006). Biogenesis and contents of the photosynthetic apparatus in leaves are disturbed by increased air pollution. The effects of different sources of pollutants, the atmospheric transport and transformations of the main phytotoxic pollutants, have been studied with due consideration given to impacts at all levels of plant organisation from molecular to ecological. Air pollution in the city has been considered as one of the most serious environmental problems (Juda-Rezler 2000; Buchan 2005). Acidic deposition and heavy metal accumulation may be contributing to plant population and plant communities declines and may cause adverse responses manifested in their growth, physiology, ecological structure and floristic composition (Drzewiecka-Matuszek et al. 2005; Nenova 2009; Zhou et al. 2011). Determination of photosynthetic pigments has been a major research subject in the study on air pollution effects on vegetation (Bell \& Treshow 2002; Merkisz et al. 2005). Many authors have reported the effects of acid rain on growth, photosynthesis and dark respiration in some trees in Asia (Shan 1993, 1998; Shan \& Feng 1989). Air pollutants can exert direct effect on plants, damage the tissue of assimilation organs in the aboveground parts or can have indirect effect by soil or water poisoning, which deteriorates the habitat conditions. Particularly adverse is the effect of ashes as when depositing on the leafs or needles they may block the stomata, which hampers the gas exchange and transpiration as well as penetration of light to chlorophyll (Maciak 2003).

In the $21^{\text {st }}$ century an important problem is to find methods of curbing the spread of air pollution along roads of heavy traffic in the cities. In open areas the air pollutants such as pollen and gases spread over large distances from roads and the land near the roads is an inert storage of pollutants. In forested areas trees act as biological filters and restrict the spreading of pollution (Maciak 2003). This observation is important in the aspect of air protection and the city ecology (Szklarczyk 2001).

The aim of this study is to assess the variability of the photosynthetic apparatus content in relation to the floristic diversity and structure of plant communities in green belts along major traffic routes of varying intensity of road traffic at selected distances from the road.

\section{Methods}

The study on variation indices of plant chlorophyll content was carried out in 2010 in Białystok, in four designated transects (3 in non-forest communities not in green belt and 1 in forest community within the green belt) which were along the main traffic routes in the province Route No. 669 between Bialystok-Ełk by Narodowych Sił Zbrojnych street (transect 1 (T1) - non forest), the national highways Route No. 8 between Bialystok-Warsaw by Anders street (transect 2 (T2) - non forest), the province Route No. 676 between Bialystok-Krynki by Raginisa street (transect 3 (T3) - non forest) and the province Route No. between 678 Bialystok-Wysokie Mazowieckie by Ciołkowskiego street (transect 4 (T4) - forest). The reference transects were the non-forest (T5) and forest transects (T6) away from the road traffic in the centre of Knyszyńska Forest (Fig. 1). The transects in the city of Bialystok were delimited at the distance of $4 \mathrm{~m}$ from the roadway. Each of them was 1 $\mathrm{m}$ in width and $25 \mathrm{~m}$ in length (Fig. 2). To determine the changes in the photosynthesizing apparatus as a function of the distance from the road, test plots of $1 \mathrm{~m}^{2}$ in size were delimited at distances of 4-5 m, 14-15 m and 24-25 m from the road. In the area of $100 \mathrm{~m}^{2}(4 \mathrm{~m} \times 25 \mathrm{~m})$ with transects and in the study plots of $1 \mathrm{~m}^{2}$, the phytosociological relevés were made by the Braun-Blanquet method, using the 6-grade quantitative scale. On the basis of the floristic list of all species identified in the phytosociological relevé on $1 \mathrm{~m}^{2}$, the fresh biomass of green plants (about $10 \mathrm{~g}$ ) was collected separately for the species identified in the transects at particular distances (4-5 m, 14-15 m and 24-25 m) from the road. The living forms of species making particular layers of the communities, i.e. leaves, needles from the trees, bushes, herbal plants and mosses, were also taken into account in the measurements from $1 \mathrm{~m}^{2}$ area. The fresh biomass was collected in foil sacks placed in envelopes labelled with the number of transect, distance from the road and species name. Measurements were performed for all species from the floristic list from $1 \mathrm{~m}^{2}$ area.

The data describing the traffic intensity on the selected roads were obtained from Kuklewicz (2012, unpublished data). Using the program Statistica 9.0, the correlations were analysed and characterised by the Pearson coefficient of linear correlations at a significance level of $\alpha=0.05$ (StatSoft 2006).

Spectrophotometric studies were performed on samples of $0.50 \mathrm{~g}$ of fresh biomass from each selected species. The plant material was tested using standard laboratory methods of plant physiology (Buczek 1996). Separate measurements of chlorophylls a and b were made by spectrophotometric methods (Wang et al. 2004; Lamb et al. 2012). In this work the total chlorophyll as well as chlorophyll a and chlorophyll b concentrations were determined in methanol 


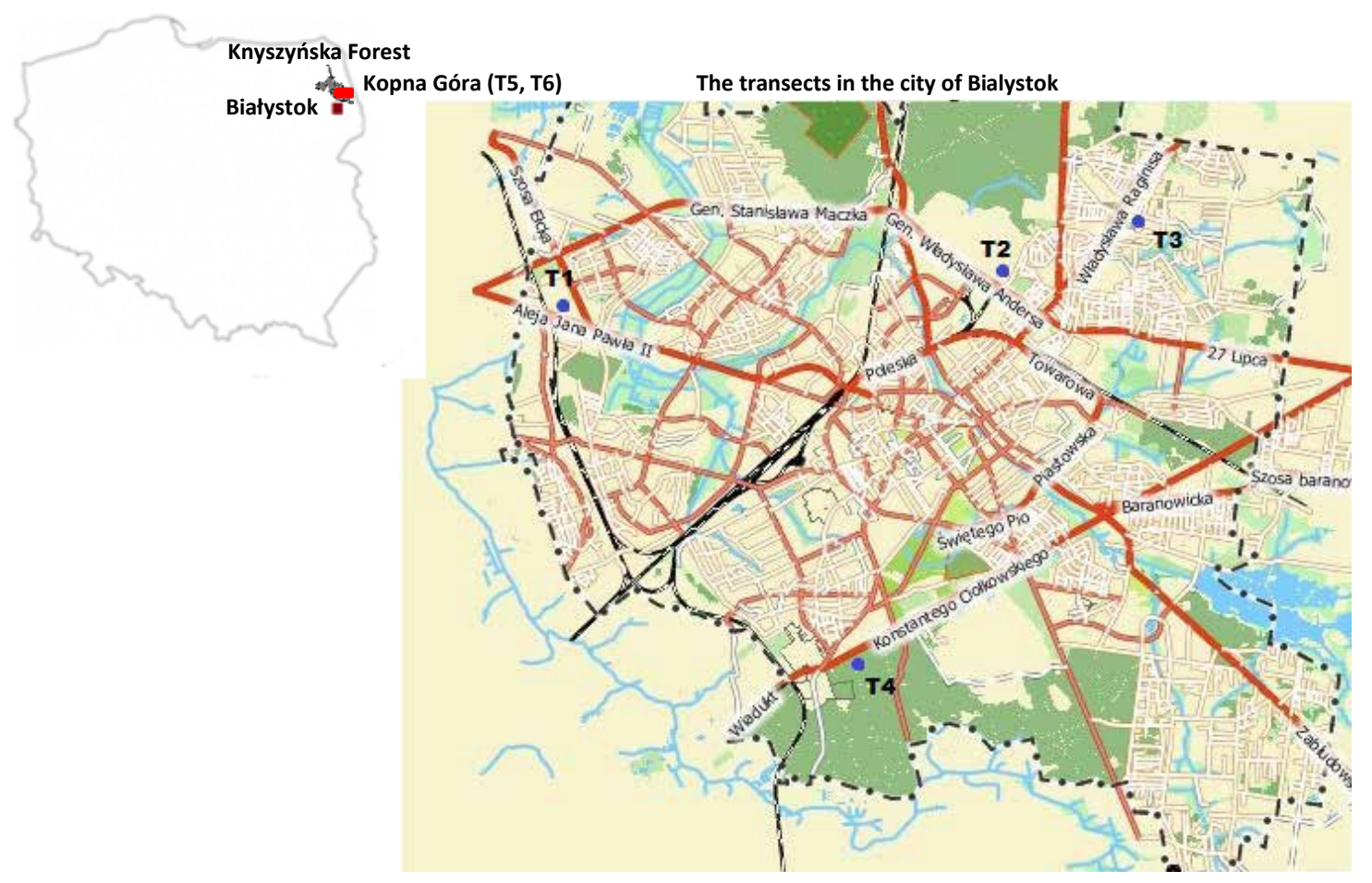

Figure 1. Location of the study area in the city of Białystok (Source: gisbialystok.pl) and in the centre of Knyszyńska Forest.

The four designated transects -3 in non-forest communities not in green belts: $\mathrm{T} 1$ - transect 1 , the main traffic routes on the province Route No. 669 BiałystokEłk by Narodowych Sił Zbrojnych street, T2 - transect 2, the national highway Route No. 8 Białystok-Warsaw by Andersa street, T3 - transect 3, the province Route No. 676 Białystok-Krynki by Raginisa street; and 1 in forest communities in green belt, T4 - transect 4, the province Route No. 678 Białystok-Wysokie Mazowieckie by Ciołkowskiego street. The two designated transects away from the road traffic in the centre of Knyszyńska Forest: T5 - non-forest transect, T6 - forest transect

Figure 2. Arrangement of permanent plots for study area in tran-

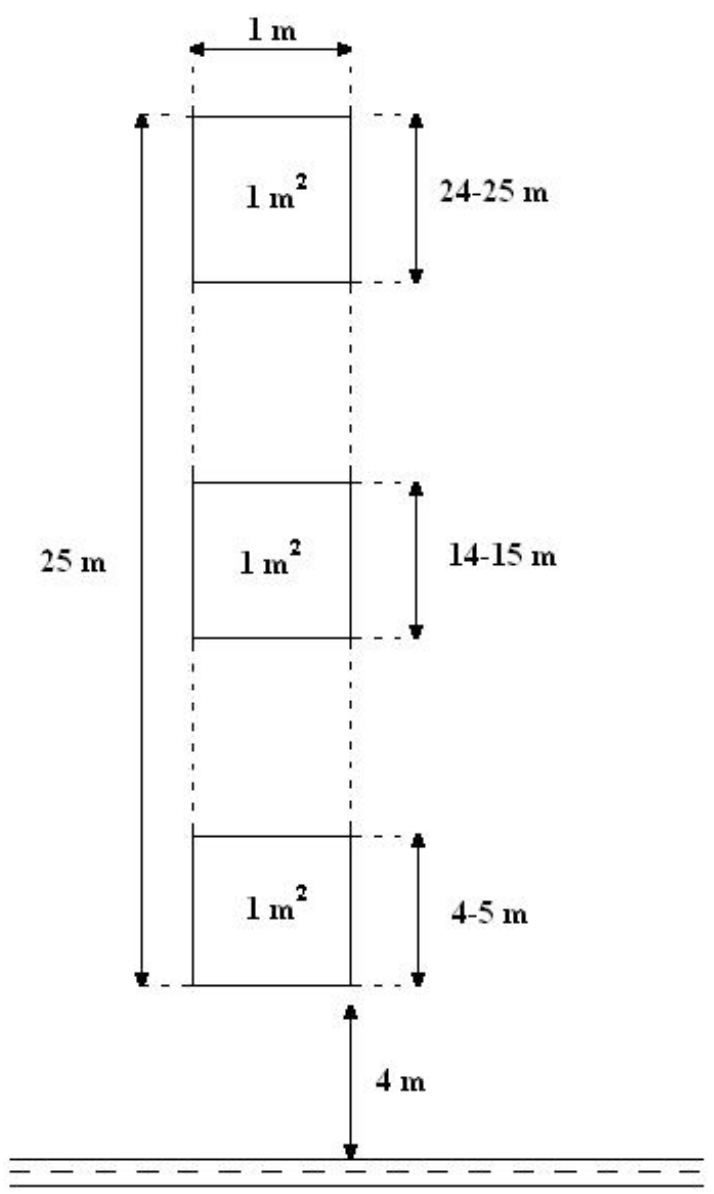
sects of the non-forest and forest communities 
extracts of photosynthetic tissue (Yamamoto et al. 2002; Lamb et al. 2012).

The absorbance read off for each species in three repetitions at $470 \mathrm{~nm}, 652.4 \mathrm{~nm}$ and $665.2 \mathrm{~nm}$. The blank sample was 100\% methanol (Buczek 1996). The concentration of chlorophyll a $\left(\mathrm{C}_{\mathrm{a}}\right)$, chlorophyll b $\left(\mathrm{C}_{\mathrm{b}}\right)$, total chlorophyll $\left(\mathrm{C}_{\mathrm{a}+\mathrm{b}}\right)$ and the sum of carotenoids $\left(\mathrm{C}_{\mathrm{x}+\mathrm{c}}\right)$ were calculated from the formulae given below. The results were expressed in milligrams of the dye per 1 gram of fresh biomass (Buczek 1996).

$$
\begin{aligned}
& \mathrm{C}_{\mathrm{a}}=16,72 \mathrm{~A}_{665,2}-9,16 \mathrm{~A}_{652,4} \\
& \mathrm{C}_{\mathrm{b}}=34,09 \mathrm{~A}_{652,4}-15,28 \mathrm{~A}_{665,2} \\
& \mathrm{C}_{\mathrm{a}+\mathrm{b}}=1,44 \mathrm{~A}_{665,2}+24,93 \mathrm{~A}_{652,4} \\
& \mathrm{C}_{\mathrm{x}+\mathrm{c}}=\frac{1000 \mathrm{~A}_{470}-1,63 \mathrm{C}_{\mathrm{a}}-104,96 \mathrm{C}_{\mathrm{b}}}{221}
\end{aligned}
$$

The equations are where:

$\mathrm{C}_{\mathrm{a}}$ - concentration of chlorophyll $a$,

$\mathrm{C}_{\mathrm{b}}$ - concentration of chlorophyll $b$,

$\mathrm{C}_{\mathrm{a}+\mathrm{b}}$ - concentration of total chlorophyll,

$\mathrm{C}_{\mathrm{x}+\mathrm{c}}$ - sum of carotenoids,

$\mathrm{A}_{665.2}^{\mathrm{x+c}}-$ absorbance read off at $665.2 \mathrm{~nm}$,

$\mathrm{A}_{652.4}$ - absorbance read off at $652.4 \mathrm{~nm}$,

$\mathrm{A}_{470}-$ absorbance read off at $470 \mathrm{~nm}$.

\section{Results}

\subsection{Floristic variation of plant communities in the transects studied}

The plant communities in the transects delimited in the city represent the forms changed under anthropogenic pressure. Their floristic composition was dominated by meadow species from the class Molinio-Arrhenatheretea and ruderal species from the class Artemisietea vulgaris. In the non-forest transect 1 (T1) a meadow community with the domination of Dactylis glomerata with single trees representing the species Quercus robur and Pinus sylvestris (10\% cover) was identified. Meadow vegetation (100\% cover) was made mainly by Rumex acetosa and Festuca rubra together with Dactylis glomerata.

In non-forest transect 2 (T2) a meadow community with Poa pratensis and Festuca rubra was found; the meadow growth cover was $100 \%$. Young brushwood of
Prunus domestic, Crataegus monogyna and Acer negundo occurred with a cover of $20 \%$.

In non-forest transect 3 (T3) a meadow community with Dactylis glomerata and Calamagrostis epigejos from the class of Molinio-Arrhenatheretea was found with single trees of Malus sylvestris and Acer platanoides (20\% cover) and bushes of Prunus domestica and Malus sylvestris (10\% cover).

The forest transect 4 (T4) was related to the habitat of a fresh mixed forest of a two-layered tree stand. Poorly developed upper layer (a1, 20\% cover) was made of Pinus sylvestris. The well-developed subcanopy layer (a2, 60\% cover) was composed of Carpinus betulus and Quercus robur, while the bush layer (40\% cover) was dominated by Corylus avellana. The herbal layer (70\% cover) was made of Agrimonia eupatoria, Rubus saxatilis and Festuca ovi$n a$, while the main species in the layer of moss (20\% cover) were Eurhynchium angustirete and Plagiomnium affine.

The non-forest reference transect 5 (T5) in the Kopna Góra Arboretum, Knyszyńska Forest was a mowed meadow community with the domination of Dactylis glomerata and Poa annua. In this community the floristically richest class was Molinio-Arrhenatheretea.

The forest reference transect (T6) in the Kopna Góra Arboretum represented the habitat of fresh mixed forest of two-layered tree stand. The upper layer of trees (a1; 40\% cover) was made of Pinus sylvestris, while the subcanopy layer (a2; 60\% cover) was made of Quercus robur. The layer of bushes is dominated by Corylus avellana. Under the forest canopy in the medium-developed herbal layer (50\% cover) the most abundant are Oxalis acetosella and Vaccinium myrtillus, while the moss layer is dominated by Eurhynchium striatum.

\subsection{Variation in the photosynthetic apparatus and intensity of road traffic}

The results obtained for non-forest city transect have shown that the content of total chlorophyll in the green biomass of the species from a given community is negatively correlated with the intensity of road traffic, i.e. the heavier the traffic the lower the content of total chlorophyll. In the biomass from T2 at the heaviest traffic of 964 motor vehicles per hour, the content of total chlorophyll was the lowest $(29.8 \mathrm{mg} / \mathrm{g}$ of fresh biomass, Table 1). In the biomass from T1 and T3, at the road traffic of 439 and 501 motor vehicles per hour, the contents of total chlorophyll varied from 52.9 to $66.1 \mathrm{mg} / \mathrm{g}$ fresh biomass (Table 1). In the biomass from the forest transect, at the heavy traffic of 860 vehicles per hour, the content of total chlorophyll was the highest $(70.9 \mathrm{mg} / \mathrm{g}$ of fresh biomass, Table 1$)$. This result suggests that the belt of forestation restricts the impact of road traffic on the concentration of total chlorophyll. 
Table 1. The content of total chlorophyll, chlorophyll a, chlorophyll b and carotenoids in the green biomass of the species [mg/g of fresh biomass] in transects of the non-forest and forest communities

\begin{tabular}{|c|c|c|c|c|c|c|}
\hline \multirow{5}{*}{ 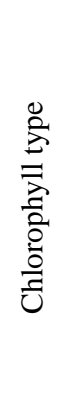 } & \multicolumn{6}{|c|}{ Transects } \\
\hline & 2010 year & 2010 & 2010 & $\begin{array}{c}\text { reference } \\
2009 \text { year (Source: Łaska, } \\
\text { not published) }\end{array}$ & 2010 & $\begin{array}{c}\text { reference } \\
2009 \text { year (Source: Laska, } \\
\text { not published) }\end{array}$ \\
\hline & $\begin{array}{l}\text { Narodowych Sił } \\
\text { Zbrojnych street }\end{array}$ & $\begin{array}{l}\text { Andersa } \\
\text { street }\end{array}$ & $\begin{array}{l}\text { Raginisa } \\
\text { street }\end{array}$ & Arboretum & $\begin{array}{c}\text { Ciołkowskiego } \\
\text { street }\end{array}$ & Arboretum \\
\hline & $\mathrm{T} 1$ & $\mathrm{~T} 2$ & T3 & T5 & $\mathrm{T} 4$ & T6 \\
\hline & non-forest & non-forest & non-forest & non-forest & forest & forest \\
\hline$C_{a+b}$ & 52.8963 & 29.7997 & 66.0487 & 38.2526 & 70.8963 & 90.3466 \\
\hline $\mathrm{C}_{\mathrm{a}}$ & 32.0561 & 18.6311 & 43.6160 & 24.8968 & 63.7940 & 51.9147 \\
\hline $\mathrm{C}_{\mathrm{b}}$ & 20.8401 & 10.0929 & 22.4327 & 13.3557 & 7.1024 & 38.3599 \\
\hline$C_{x+c}$ & 4.9126 & 3.6062 & 7.5704 & 5.4660 & 20.9041 & 6.5755 \\
\hline
\end{tabular}

In the biomass from the non-forest reference transect $\mathrm{T}$, beyond direct impact of road traffic, in the neutral zone of accessibility of ashes and gases related to motor vehicles, the content of total chlorophyll was found to be $38.3 \mathrm{mg} / \mathrm{g}$ of fresh biomass. This value was higher than that determined in the biomass from T2 where the photosynthesis was strongly disturbed by heavy traffic. In the biomass of forest reference transect (T6), outside the city and beyond direct impact of road traffic, the content of total chlorophyll was $90.4 \mathrm{mg} / \mathrm{g}$ of fresh biomass so it was higher than in the biomass from the forest transect in the city (T4) (70.9 mg/g of fresh biomass).

The high contents of total chlorophyll can be related to better availability of mineral compounds or better insolation conditions. The contents of chlorophyll a in green biomass from both forest and non-forest transects are 1.5-2 times higher than those of chlorophyll b (Table 1), the only exception was the content of chlorophyll $b$ in the biomass from the forest transect in the city (T4) which was the lowest of all, $7.1 \mathrm{mg} / \mathrm{g}$ fresh biomass, (Table 1) as determined from the ratio of chlorophyll a to chlorophyll b.

\subsection{Variation in the photosynthetic apparatus and the distance from the road}

The content of chlorophyll in green biomass from all plant communities was correlated with the distance from the road (Fig. 3). The contents of total chlorophyll in plant communities are statistically significantly correlated to the content of total chlorophyll determined in the biomass of the species growing closest to the road $(4-5 \mathrm{~m})(\mathrm{r}=0.94)$. The highest content of chlorophyll a was found at a distance of
14-15 m ( $\mathrm{r}=0.97)$ from the road, while the highest content of chlorophyll b - at a distance of 24-25 m ( $\mathrm{r}=0.97)$, and the highest content of carotenoids - at a distance 4-5 m $(r=0.99)$. It follows from the fact that the higher the content of total chlorophyll in green biomass, the more chlorophyll occurs in the green biomass at the closest distance to the road (Fig. 3). It is most probably related to the fact that at the closest distance to the road the process of photosynthesis is disturbed to the greatest degree by the impact of road traffic. In the forest and non-forest communities in the city, analysis of the content of total chlorophyll versus the distance from the road (4-5 m, 14-15 m, 24-25 m) has not brought a clear correlation (Fig. 4). In the non-forest reference transect (T5) the concentration of total chlorophyll in green biomass increased with increasing distance of biomass collection point from the road. In the forest reference transect (T6) the highest content of total chlorophyll was found in the biomass collected at a distance 4-5 $\mathrm{m}$ from the road, where the tree canopies were less compact. Farther away from the road, where tree canopies were more compact and determined the access of light to the forest floor, the content of total chlorophyll was lower (Fig. 4).

\subsection{Variation of the photosynthetic apparatus in green biomass of trees, bushes, herbal plants and mosses}

Analysis of the results has shown that in all non-forest communities, both in the city and outside it, high contents of total chlorophyll were correlated with the high content of chlorophyll in the biomass of herbal plants (Table 2, Fig. 5). Interestingly, in the non-forest city transects the content of total chlorophyll in green biomass determined in 

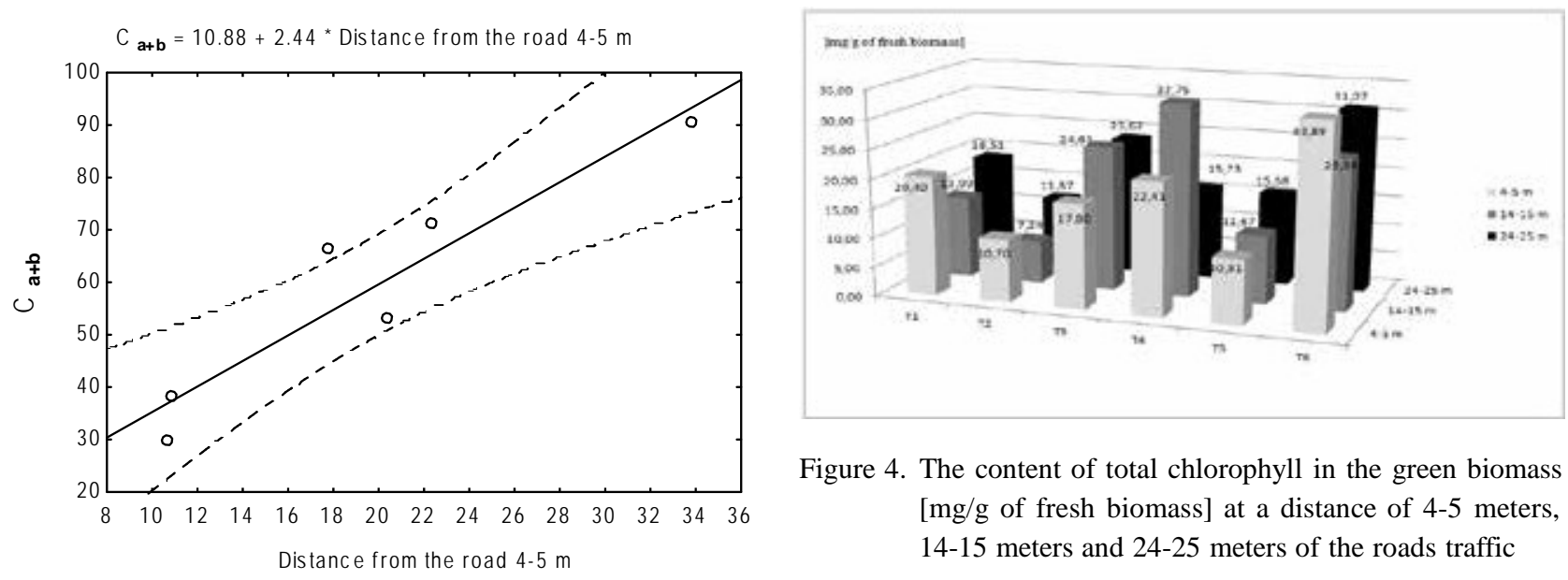

Figure 4. The content of total chlorophyll in the green biomass [mg/g of fresh biomass] at a distance of 4-5 meters, 14-15 meters and 24-25 meters of the roads traffic
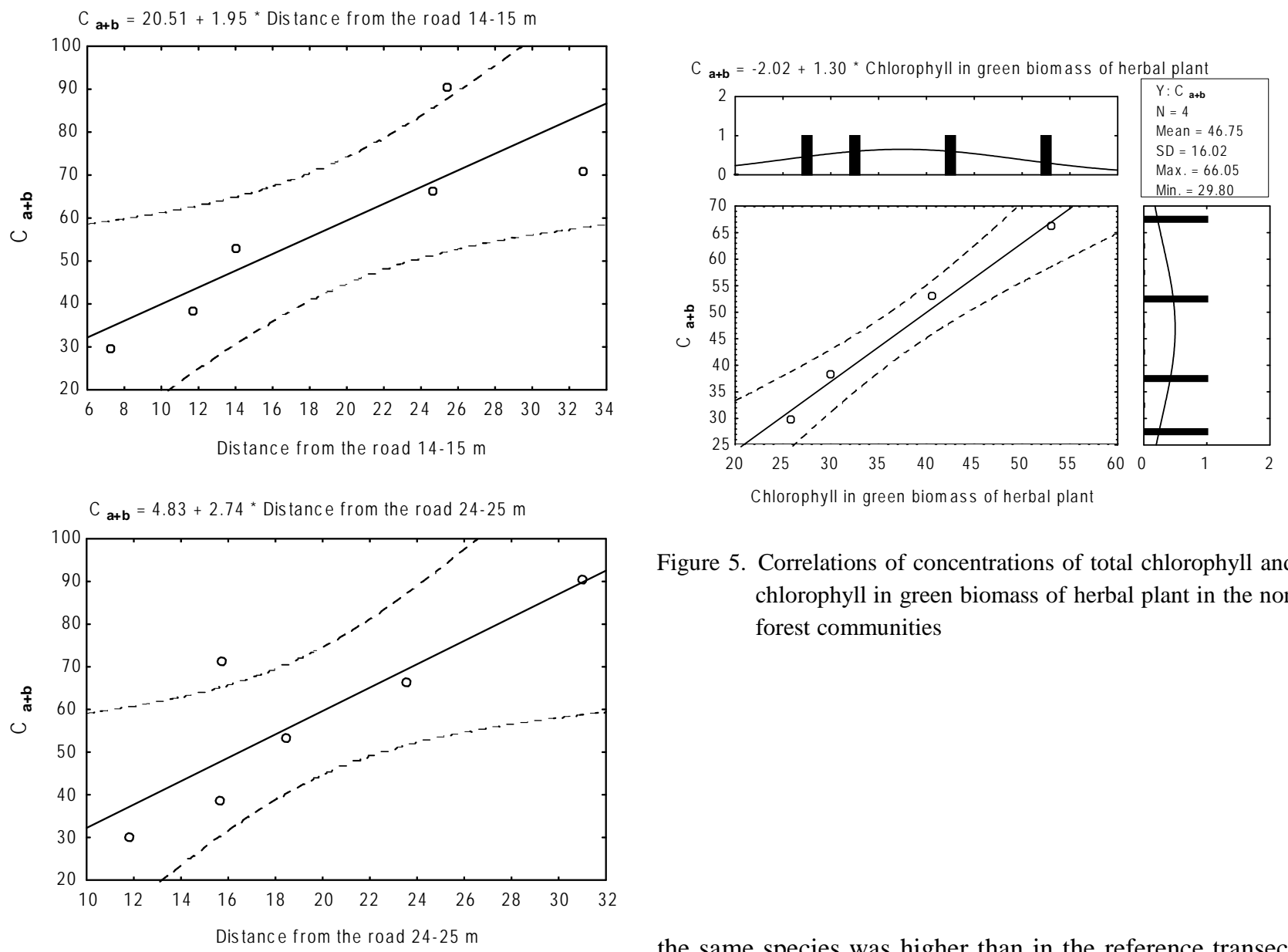

Figure 5. Correlations of concentrations of total chlorophyll and chlorophyll in green biomass of herbal plant in the non forest communities

Figure 3. Correlations of concentrations of total chlorophyll in green biomass and the distance from the road a) of 4-5 meters and b) of 14-15 meters and c) of 24-25 meters

the same species was higher than in the reference transect (Fig. 6). The situation was different in the forest transects, where the content of total chlorophyll was determined mainly by that in green biomass of trees and bushes (Table 2). Moreover, in deciduous species higher content of total chlorophyll was noted in the forest reference transect, while in coniferous species - in the forest city transect (Fig. 7). Thus, the floristic composition of plant communities and their structure have great effect on the variation in the content of photosynthesising dyes. 
Table 2. The content of total chlorophyll in the green biomass of the trees, bushes, herbal plants and mosses [mg/g of fresh biomass] in transects of the non-forest and forest communities

\begin{tabular}{|c|c|c|c|c|c|c|}
\hline \multirow{5}{*}{ Life-form } & \multicolumn{6}{|c|}{ Transects } \\
\hline & 2010 year & 2010 & 2010 & $\begin{array}{c}\text { reference } \\
2009 \text { year (Source: } \\
\text { Łaska, not published) }\end{array}$ & 2010 & $\begin{array}{c}\text { reference } \\
2009 \text { year (Source: } \\
\text { Łaska, not published) }\end{array}$ \\
\hline & $\begin{array}{l}\text { Narodowych Sił } \\
\text { Zbrojnych street }\end{array}$ & $\begin{array}{c}\text { Andersa } \\
\text { street }\end{array}$ & Raginisa street & Arboretum & $\begin{array}{c}\text { Ciołkowskiego } \\
\text { street }\end{array}$ & Arboretum \\
\hline & $\mathrm{T} 1$ & $\mathrm{~T} 2$ & T3 & $\mathrm{T} 5$ & $\mathrm{~T} 4$ & T6 \\
\hline & non-forest & non-forest & non-forest & non-forest & forest & forest \\
\hline Trees & 5.6584 & 4.4861 & 7.7972 & 6.9591 & 23.8577 & 42.1472 \\
\hline Bushes & - & - & - & - & 7.9346 & 12.9732 \\
\hline Herbal plants & 40.6026 & 25.8195 & 53.1561 & 30.0398 & 25.7559 & 35.7249 \\
\hline Mosses & 5.0659 & 0.7379 & 5.0954 & 1.2536 & 4.8542 & 7.0006 \\
\hline
\end{tabular}

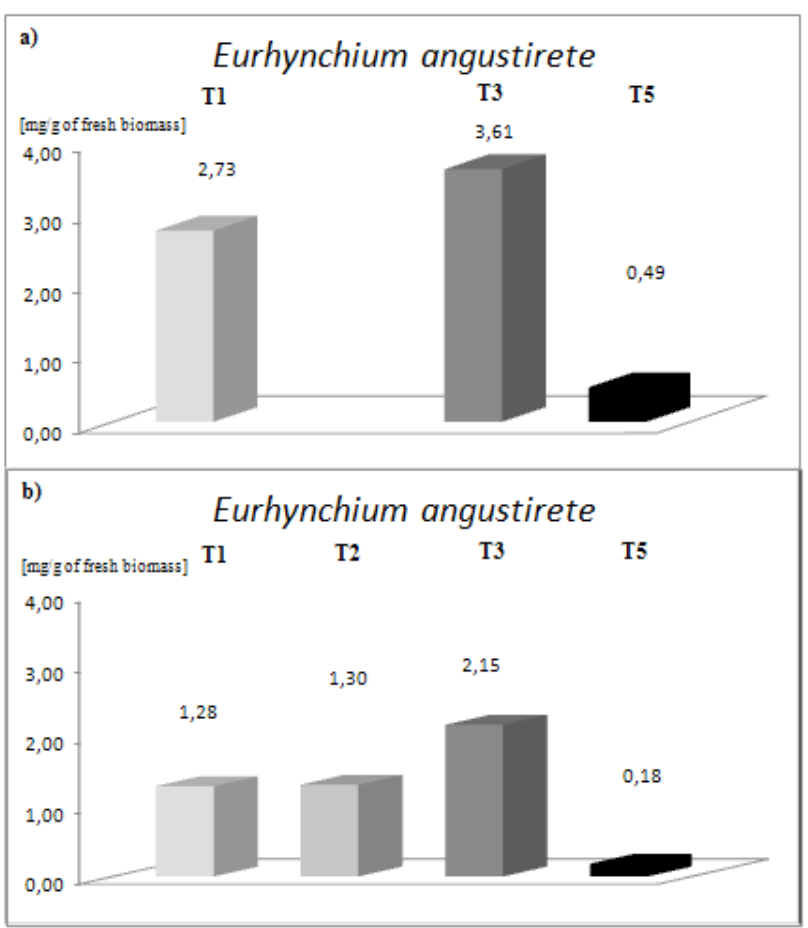

Figure 6. The content of total chlorophyll in the green biomass of Eurhynchium angustirete [mg/g of fresh biomass] at a distance a) of 4-5 $\mathrm{m}$ and b) of 14-15 $\mathrm{m}$ in transects of non-forest communities

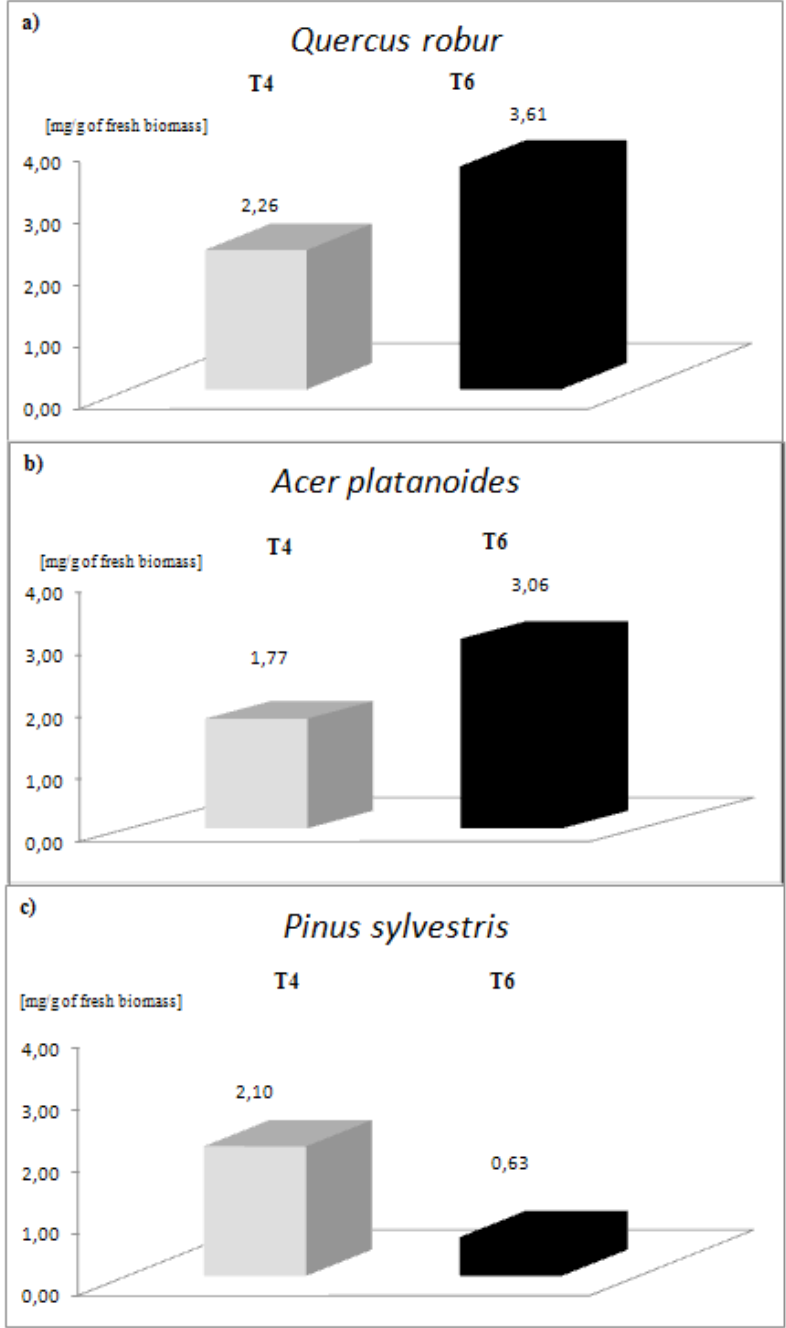

Figure 7. The content of total chlorophyll in the green biomass [mg/g of fresh biomass] in deciduous species (a) Quercus robur and b) Acer platanoides (higher content was recorded in the forest reference transect), and in coniferous species c) Pinus sylvestris (higher content was recordet in the city forest transect) 


\section{Discussion}

The photosynthetic apparatus can be considered as a part of phytocenosis, plant population, plant or a plant cell that assimilates carbon dioxide in the process of photosynthesis. The magnitude of the photosynthetic apparatus can be evaluated on the basis of measurement of the amount of green tissue involved in photosynthesis, directly correlated to the measurement of biomass as green standing crop, leaf area index and content of chlorophyll (photosynthesising dyes) (Barcikowski 1996).

Absorption of light in the process of photosynthesis is realised by the photosynthesising dyes in higher plants, mainly chlorophylls a and b, assisted by carotenoids (Richardson et al 2002; Kozłowska \& Politycka 2007). Photosynthesis is the process of synthesis of simple organic compounds (sugars) from mineral substances (carbon dioxide and water) employing the visible light energy, in the presence of assimilating dyes (Krzywański \& WójcikWojtkowiak 2002). The process of photosynthesis depends on many internal and external (environmental) factors (Pakrasi et al. 2001; Mediavilla \& Escudero 2003; Neufeld et al. 2006; Peguero-Pina et al. 2008). The internal factors include the anatomical structure and age of a leaf, arrangement and activity of chloroplasts and the content of photosynthetic dyes, while the most important environmental factors are the accessibility of light, carbon dioxide, water and temperature (Gruber \& Kosegarten 2002; Kozłowska \& Politycka 2007). The effect of environmental factors is combined and complex, the intensity of photosynthesis is restricted by the factor whose value is considerably different from the optimum one. At dawn and dusk, in spring and in the end of summer the restricting factor is the deficiency of light, in the morning the restricting factor is too low temperature, while at noon - it is the deficiency of carbon dioxide as a result of stomata closure (Kozłowska \& Politycka 2007).

In this study an attempt was made to assess the variation in the plant photosynthetic apparatus versus the species composition and structure of the plant communities in the vicinity of main roads in Bialystok with heavy traffic. According to the results, the content of total chlorophyll in green biomass of the species building a given community is significantly correlated with the intensity of road traffic and with the distance of the site of biomass collection from the road. It has been shown that the content of total chlorophyll in green biomass is the greater the more chlorophyll is in the biomass collected at the closest distances to the road. Road traffic has the greatest impact on temperature, humidity, presence of exhaust gases and ashes at the closest distances to the road (Tait \& Hik 2003; Santos 2004; Jifon et al. 2005; Daas et al. 2008). This impact is reflected in assimilation of $\mathrm{CO}_{2}$ and the process of photosynthesis and changes in the photosynthetic apparatus. In forest com- munities, the changes in the photosynthetic apparatus can be related to decreasing light accessibility with growing distance from the road (Hoel \& Solhaug 1998; Gopal et al. 2005; Gratani et al. 2006). The leaves of the undergrowth layer and herbal plant layer get less light and thus their photosynthetic activity decreases. On the other hand, too much light can also by harmful as can lead to damage to the photosynthetic apparatus. High content of carotenoid dyes in chloroplasts protects the membranes against too strong irradiation by dissipation of the excessive light energy (Terashima \& Saeki 1983; Kozłowska \& Politycka 2007; Uddling et al. 2007).

The availability of mineral elements also influences the content of photosynthetic dyes, especially those that are components of chlorophyll, proteins and that are involved in electron transfer in the light reaction phase, nitrogen, magnesium, iron, sulphur, manganese, phosphorus and potassium (Balakrishnan et al. 2000; Candan \& Tarhan 2003; Pinkard et al. 2006; Nenova 2009; Zhou et al. 2011). The deficiency of nitrogen, magnesium and iron hinders the synthesis of chlorophyll, while the deficiency of magnesium causes a decrease in the content of chlorophyll, especially in older leaves (Abadía et al. 1996; Kozłowska \& Politycka 2007).

The vertical structure and species composition also influence the status of photosynthetic apparatus. In the non-forest communities the high content of chlorophyll was the strongest correlated with the chlorophyll content in the biomass of herbal plants, while in the forest communities - with the chlorophyll content in green biomass of trees and bushes. Seasonal loss of leaves prevents the accumulation of atmospheric pollution related to road traffic in green tissues, which may happen in perennial plants. The loss of leaves can contribute to the variation in the content of photosynthetic dyes in the biomass of trees, bushes and herbal plants. Moreover, the loss of leaves is responsible for shortened photosynthetic activity of leaves but it also contributes to their higher resistance to air pollution related to road traffic. At very high concentrations of pollutants all plant species die, but there are species more and less sensitive to air pollution emitted by motor vehicles (Szymański 2000). The most resistant to air pollutants are Fagus sylvatica L., Acer campestre L., Quercus rubra L., Betula sp., Populus $\times$ berolinensis (K. Koch) Dippel, Robinia pseudoacacia L., Tilia cv. euchlora and Tilia tomentosa Moench, Pinus nigra J.F. Arnold and Taxus baccata L. Less resistant are Quercus robur L. and Q. petraea (Matt.) Liebl., Acer pseudoplatanus L. and A. platanoides L., Fraxinus excelsior L., Alnus glutinosa (L.) Gaertn., and A. incana (L.) Moench, Populus nigra L., Pseudotsuga menziesii (Mirb.) Franco, Larix decidua Mill. and Abies concolor (Gord. et Glend.) Lindl. ex Hildebr. The sensitive species include Tilia cordata Mill., Aesculus hippocastanum L., Ulmus sp. and Picea pungens Engelm. Finally the group of highly 
sensitive species comprises Abies alba Mill., Picea abies (L.) H. Karst., Pinus sylvestris L., Pinus banksiana Lamb. and Tilia platyphyllos Scop. (Szymański 2000). The species sensitivity to motor vehicle emissions should be taken into regard in designing green areas in the vicinity of roads, acting as a biological barrier protecting against spreading of air pollution.

\section{References}

Abadía A., Gil E., Morales F., Montańés L., Montserrat G. \& Abadía J., 1996, Marcescence and senescence in a sub-Mediterranean oak (Quercus subpyrenaica E. H. del Villar): photosynthetic characteristics and nutrient composition, Plant, Cell and Environment 19: 685-694.

Balakrishnan K., Rajendran C. \& Kulandaivelu G., 2000, Differential responses of iron, magnesium, and zinc deficiency on pigment composition, nutrient content, and photosynthetic activity in tropical fruit crops, Photosynthetica 38: 477-479.

Barcikowski A., 1996, Biomass and chlorophyll of photosynthesizing organs of plant communities in secondary succession in pine forest habitat, Photosynthetica 32: 63-76. Bell J. N. B. \& Treshow M., 2002, Zanieczyszczenie powietrza a życie roślin [The air pollution and the plants' life], WNT, Warszawa.

Berg A. K. \& Perkins T. D., 2004, Evaluation of a portable chlorophyll meter to estimate chlorophyll and nitrogen contents in sugar maple (Acer saccharum Marsh.) leaves, Forest Ecology and Management 200: 113-117.

Buchan W., 2005, Zanieczyszczenia powietrza [The air pollution], PWN, Warszawa.

Buczek J., 1996, Ćwiczenia z fizjologii roślin [Practice with plants' physiology], Wydawnictwo Uniwerstetu Wrocławskiego, Wrocław.

Camejo D., Rodriguez P., Morales M. A., Dell'Amico J. M., Torrecillas A. \& Alarcon J. J., 2005, High temperature effects on photosynthetic activity of two tomato cultivars with different heat susceptibility, Journal of Plant Physiology 162: 281-289.

Candan N. \& Tarhan L., 2003, Relationship among chlorophyll-carotenoid content, antioxidant enzyme activities and lipid peroxidation levels by Mg2+ deficiency in the Mentha pulegium leaves, Plant Physiology and Biochemistry 41: 35-40.

Chang S. X. \& Robinson D. J., 2003, Nondestructive and rapid estimation of hardwood foliar nitrogen status using the SPAD-502 chlorophyll meter, Forest Ecology and Management 181: 331-338.

Daas C., Montpied P., Hanchi B. \& Dreyer E., 2008, Responses of photosynthesis to high temperatures in oak saplings assessed by chlorophyll-a fluorescence: inter-specific diversity and temperature induced plasticity, Annals of Forest Sciences 65, Champenoux: 305.
Drzewiecka-Matuszek A., Skalna A., Karocki A., Stochel G. \& Fiedor L., 2005, Effects of heavy central metal on the ground and excited states of chlorophyll, Journal of Biological Inorganic Chemistry 10: 453-462,

Gopal K., Pattanayak G. K., Biswal A. K., Reddy V. S. \& Tripathy B. C., 2005, Light-dependent regulation of chlorophyll b biosynthesis in chlorophyllide a oxygenase overexpressing tobacco plants, Biochemical and Biophysical Research Communications 326: 466-471.

Gratani L., Covone F. \& Larcher W., 2006, Leaf plasticity in response to light of three evergreen species of the Mediterranean maquis, Trees 20: 549-558.

Gruber B. \& Kosegarten H., 2002, Depressed growth of non-chlorotic vine grown in calcareous soil is an iron deficiency symptom prior to leaf chlorosis, Journal of Plant Nutrition and Soil Science 165: 111-117,

Hoel B. O. \& Solhaug K. A., 1998, Effect of irradiance on chlorophyll estimation with the Minolta SPAD-502 leaf chlorophyll meter, Annals of Botany 82: 389-392.

Hörtensteiner S. \& KräutlerB., 2000, Chlorophyllbreakdown in oilseed rape, Photosynthesis Research 64: 137-146.

Jifon J. L., Syvertsen J. P. \& Whaley E., 2005, Growth environment and leaf anatomy affect non-destructive estimates of chlorophyll and nitrogen in Citrus sp. leaves, Journal of the American Society for Horticultural Science 130: 152-158.

Juda-Rezler K., 2000, Oddziaływanie zanieczyszczeń powietrza na środowisko [Influence on environment the pollutions of air], Oficyna Wydawnicza Politechniki Warszawskiej, Warszawa.

Kozłowska M. \& Politycka B., 2007, Fizjologia roślin [Plants’ physiology], PWRiL, Poznań.

Krzywański Z. \& Wójcik-Wojtkowiak D., 2002, Zarys fizjologii roślin. Wykłady i ćwiczenia [Profile of the plants' physiology. Lectures and practice], Wydawnictwo Akademii Rolniczej, Poznań.

Lamb J. J, Eaton-Rye J. J. \& Hohmann-Marriott M. N., 2012, An LED-based fluorometer for chlorophyll quantification in the laboratory and in the field, Photosynthesis Research 114: 59-68.

Maciak F., 2003, Ochrona i rekultywacja środowiska [The protection and the recultivation of environment], SGGW, Warszawa.

MacIntyre H. L., Kana T. M., Anning T. \& Geider R. J., 2002, Photoacclimation of photosynthesis irradiance response curves and photosynthetic pigments in microalgae and cyanobacteria, Journal of Phycology 38: 17-38.

Mediavilla S. \& Escudero A., 2003, Photosynthetic capacity, integrated over the lifetime of a leaf, is predicted to be independent of leaf longevity in some tree species, New Phytologist 159: 203-211.

Merkisz J., Piekarski W. \& Słowik T., 2005, Motoryzacyjne zanieczyszczenia środowiska [Automotive pol- 
lutions of environment], Wydawnictwo Akademii Rolniczej, Lublin.

Moran J. A., Mitchell A. K., Goodmanson G. \& Stockburguer K. A., 2000, Differentiation among effects of nitrogen fertilization treatments on conifer seedlings by foliar reflectance: a comparison of methods. Tree Physiology 20: 1113-1120.

Nenova V. R., 2009, Growth and photosynthesis of pea plants under different iron supply, Acta Physiologiae Plantarum 31: 385-391.

Neufeld H. S., Chappelka A. H., Somers G. L., Burkey K. O., Davison A. W. \& Finkelstein P. L., 2006, Visible foliar injury caused by ozone alters the relationship between SPAD meter readings and chlorophyll concentrations in cutleaf coneflower, Photosynthesis Research 87: 281-286.

Pakrasi H., Ogawa T. \& Bhattacharrya-Pakrasi M., 2001, Transport of metals: a key process in oxygenic photosynthesis, [in:] E. M. Aro, B. Anderson (eds), Regulation of photosynthesis, Kluwer, Dordrecht: 253-264.

Peguero-Pina J. J., Morales F., Gil-Pelegrín E., 2008, Frost damage in Pinus sylvestris L. stems assessed by chlorophyll fluorescence in cortical bark chlorenchyma, Annals of Forest Sciences 65.

Pinkard E. A., Patel V. \& Mohammed C., 2006, Chlorophyll and nitrogen determination for plantation-grown Eucalyptus nitens and E. globulus using a non-destructive meter, Forest Ecology and Management 223: 211-217.

Porra R. J., 2002, The chequered history of the development and use of simultaneous equations for the accurate determination of chlorophylls a and b, Photosynthesis Research 73: 149-156.

Radyuk M. S. \& Homan N. M., 2002, Discrete character of the development of the photosynthetic apparatus in greening barley leaves, Photosynthesis Research 72: 117-122.

Richardson A. D., Duigan S. P. \& Berlyn G. P., 2002, An evaluation of non-invasive methods to estimate foliar chlorophyll content, New Phytologist 153: 185-194.

Ritchie R. J., 2006, Consistent sets of spectrophotometric chlorophyll equations for acetone, methanol and ethanol solvents, Photosynthesis Research 89: 27-41.

Rüdiger W., 2002, Biosynthesis of chlorophyll b and the chlorophyll cycle, Photosynthesis Research 74: 187193.

Sanmartin P., Villa F., Silva B., Cappitelli F. \& Prieto B., 2011, Color measurements as a reliable method for estimating chlorophyll degradation to phaeopigments, Biodegradation 22: 763-771.

Santos C. V., 2004, Regulation of chlorophyll biosynthesis and degradation by salt stress in sunflower leaves, Scientia Horticulturae 103: 93-99.

Scarpari L. M., Meinhardt L. W., Maizzafera P., Pomella A. W. V., Schiavinato M. A., Cascardo J. C. M. \& Pereira
G. A. G., 2005, Biochemical changes during the development of witches' broom: the most important disease of cocoa in Brazil caused by Crinipellis perniciosa, Journal of Experimental Botany 56: 865-877.

Shan Y., 1993, Air Pollution, Acid Rain and Plants, The Environmental Sciences, China.

Shan Y., 1998, Effects of simulated acid rain on Pinus densiflora: inhibition of net photosynthesis by the pheophytization of chlorophyll, Water, Air, and Soil Pollution 103: 121-127.

Shan Y. \& Feng Z., 1989, Acid rain and Agriculture, Chinese Forestry Press: 174-177.

Silla F., Gonzalez-Gil A., Gonzalez-Molina M. A., Mediavilla S. \& Escudero A., 2010, Estimation of chlorophyll in Quercus leaves using a portable chlorophyll meter: effects of species and leaf age, Annals of Forest Sciences 67: 108p1-108p7.

StatSoft 2006, Elektroniczny Podręcznik Statystyki PL [Electronic Textbook of Statistics PL], Kraków.

Szklarczyk M., 2001, Ochrona atmosfery [Protection of atmosphere], Wydawnictwo Uniw. Warmińsko-Mazurskiego, Olsztyn.

Szymański S., 2000, Ekologiczne podstawy hodowli lasu [Ecological bases of farming of forest], PWRiL, Warszawa.

Tait M. A. \& Hik D. S., 2003, Is dimethylsulfoxide a reliable solvent for extracting chlorophyll under field conditions? Photosynthesis Research 78: 87-91.

Terashima I. \& Saeki T., 1983, Light environment within a leaf, Plant and Cell Physiology 24: 1493-1501.

Timperio A. M., D’Amici G. M., Barta C., Loreto F. \& Zolla L., 2007, Proteomics, pigment composition, and organization of thylakoid membranes in iron-deficient spinach leaves, Journal of Experimental Botany 58: 3695-3710.

Uddling J., Gelang-Alfredsson J., Piikki K. \& Pleijel H., 2007, Evaluating the relationship between leaf chlorophyll concentration and SPAD-502 chlorophyll meter readings, Photosynthesis Research 91: 37-46.

Wang Q. B., Chen M. J. \& Li Y. C., 2004, Nondestructive and rapid estimation of leaf chlorophyll and nitrogen status of peace lily using a chlorophyll meter, Journal of Plant Nutrition 27: 557-569.

Yamamoto A., Nakamura T., Adu-Gyamfi J. J. \& Saigusa M., 2002, Relationship between chlorophyll content in leaves of sorghum and pigeonpea determined by extraction method and by chlorophyll meter (SPAD-502), Journal of Plant Nutrition 25: 2295-2301.

Zhou M., Gong X., Ying W., Chao L., Hong M., Wang L. \& Fashui H., 2011, Cerium Relieves the Inhibition of Chlorophyll Biosynthesis of Maize Caused by Magnesium Deficiency, Biological Trace Element Research 143: 468-477. 